\section{Pacific Northwest}

National Laboratory

Operated by Battelle for the

U.S. Department of Energy

\section{Initial Investigation of Waste Feed Delivery Tank Mixing and Sampling Issues}

J. A. Fort

J. A. Bamberger

P. A. Meyer

C. W. Stewart

October 2007

Prepared for the U.S. Department of Energy under Contract DE-AC05-76RL01830 


\section{DISCLAIMER}

This report was prepared as an account of work sponsored by an agency of the United States Government. Neither the United States Government nor any agency thereof, nor Battelle Memorial Institute, nor any of their employees, makes any warranty, express or implied, or assumes any legal liability or responsibility for the accuracy, completeness, or usefulness of any information, apparatus, product, or process disclosed, or represents that its use would not infringe privately owned rights. Reference herein to any specific commercial product, process, or service by trade name, trademark, manufacturer, or otherwise does not necessarily constitute or imply its endorsement, recommendation, or favoring by the United states Government or any agency thereof, or Battelle Memorial Institute. The views and opinions of authors expressed herein do not necessarily state or reflect those of the United States Government or any agency thereof.

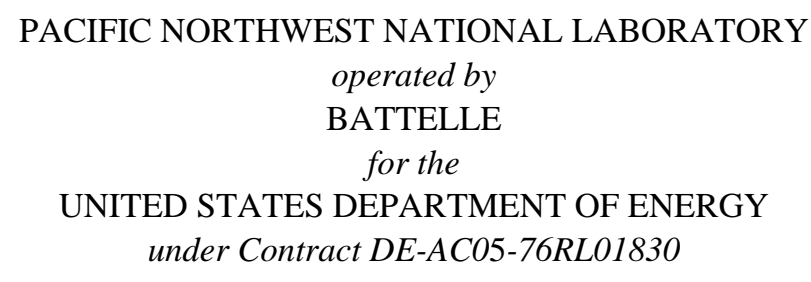

Printed in the United States of America

$$
\begin{aligned}
& \text { Available to DOE and DOE contractors from the } \\
& \text { Office of Scientific and Technical Information, } \\
& \text { P.O. Box 62, Oak Ridge, TN 37831-0062; } \\
& \text { ph: (865) 576-8401 } \\
& \text { fax: (865) 576-5728 } \\
& \text { email: reports@adonis.osti.gov }
\end{aligned}
$$

\footnotetext{
Available to the public from the National Technical Information Service, U.S. Department of Commerce, 5285 Port Royal Rd., Springfield, VA 22161 ph: (800) 553-6847 fax: (703) 605-6900 email: orders@ntis.fedworld.gov online ordering: http://www.ntis.gov/ordering.htm
} 


\title{
Initial Investigation of Waste Feed Delivery Tank Mixing and Sampling Issues
}

\author{
J. A. Fort \\ J. A. Bamberger \\ P. A. Meyer \\ C. W. Stewart
}

October 2007

Prepared for

the U.S. Department of Energy

under Contract DE-AC05-76RL01830

Pacific Northwest National Laboratory

Richland, Washington 99354 


\section{Summary}

The Hanford tank farms contractor will deliver waste to the Waste Treatment Plant (WTP) from a staging double-shell tank (DST). The WTP broadly classifies the waste it receives in terms of "Envelopes," each with different limiting properties and composition ranges. Envelope A, B, and C wastes are liquids that can include up to $4 \%$ entrained solids that can be pumped directly from the staging DST without mixing. Envelope D waste contains insoluble solids and must be mixed before transfer. The mixing and sampling issues lie within Envelope D solid-liquid slurries. The question is how effectively these slurries are mixed and how representative the grab samples are that are taken immediately after mixing.

This report summarizes the current state of knowledge concerning jet mixing of wastes in underground storage tanks. Waste feed sampling requirements are listed, and their apparent assumption of uniformity by lack of a requirement for sample representativeness is cited as a significant issue. The case is made that there is not an adequate technical basis to provide such a sampling regimen-not enough is known about what can be achieved in mixing and distribution of solids by use of the baseline submersible mixing pump system. A combined mixing-sampling test program is recommended to fill this gap. Historical Pacific Northwest National Laboratory project and tank farms contractor documents are used to make this case.

A substantial investment and progress are being made to understand mixing issues at the WTP. A summary of the key WTP activities relevant to this project is presented in this report. The relevant aspects of the WTP mixing work, together with a previously developed scaled test strategy for determining solids suspension with submerged mixer pumps (discussed in Section 3) provide a solid foundation for developing a path forward. 


\section{Acronyms and Abbreviations}

CH2MHILL

DST

HP

$\mathrm{Pa}$

PNNL

psi

RDQO

SRS

TFC

$\mathrm{U}_{0} \mathrm{D}_{0}$

WTP
CH2M HILL Hanford Group, Inc.

double-shell tank

horsepower

Pascal

Pacific Northwest National Laboratory

pounds per square inch

Regulatory Data Quality Objectives

Savannah River Site

Tank Farm Contractor

product of exit velocity and nozzle diameter

Waste Treatment and Immobilization Plant 


\section{Glossary}

Mobilization In terms of jet mixed tank waste, mobilization of settled solids implies that the mixer pump jet can penetrate the settled solids layer, which may have significant cohesive strength, breaking the solids layer up and lifting these solids into the liquid layer above.

Suspension

Solids that are mobilized will be held in suspension for an amount of time that depends on the solids settling rate and the persistence of fluid jet agitation that moves the solids higher in the tank. The settling rate is a function of particle size, fluid viscosity, and density ratio between the particle and fluid.

Agglomerated solids that are lifted off the tank floor may resettle as soon as the jet passes, whereas fine particulates that are mobilized by the jet will follow the fluid circulation in the tank and can remain suspended for long periods of time.

Uniformity In terms of mixing of waste tank contents, uniformity is the relative measure of homogeneity of the fluid-solid particulate mixture. Complete homogeneity may be desirable but is usually not achieved in plant scale vessels except for small diameter, low density particles. This condition can typically only be approached with large applied mixing power to the system. In part because of thermal concerns, applied power and therefore level of uniformity will be limited in underground storage and feed delivery tanks at Hanford.

Representativeness

When referring to sampling, this is the quality of being representative of the medium being sampled. Sampling by its nature is a selective acquisition of a larger whole. If that larger whole is homogeneous, representative sampling is easy. When the whole is highly inhomogeneous, such as in mobilization and mixing of particulate solids with varied particle sizes and localized and cyclic mixing jet agitation, it is not easy for selective sampling to be representative of the system. Number of samples, location of samples, and kinds of samples may be important in this case. 


\section{Contents}

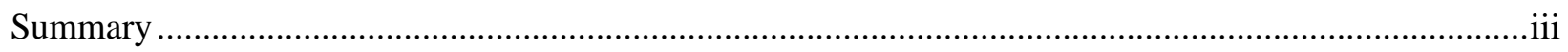

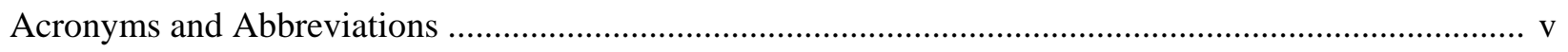

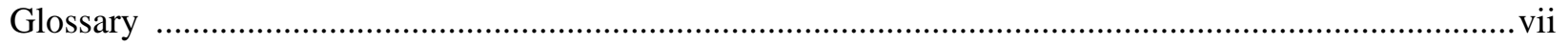

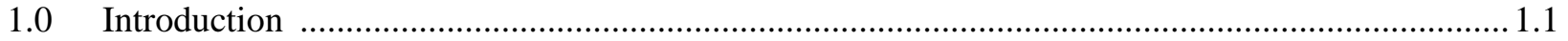

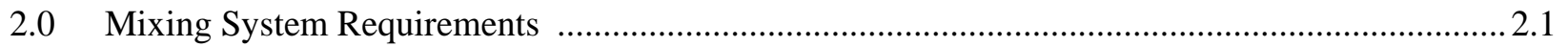

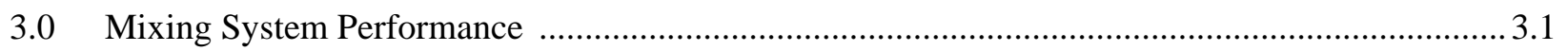

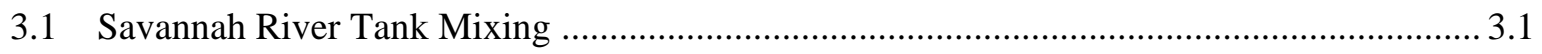

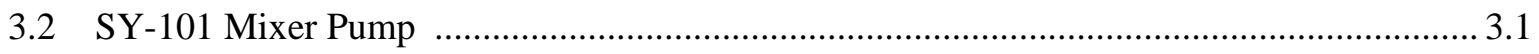

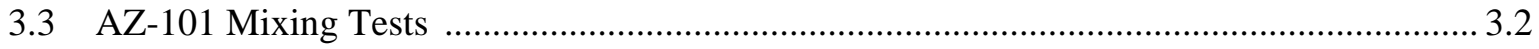

3.4 W-211 Mixer Pump Development ………......................................................................... 3.2

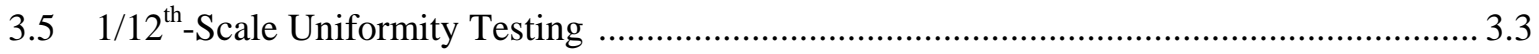

4.0 Relevant Activities in the WTP Mixing Program .................................................................. 4.1

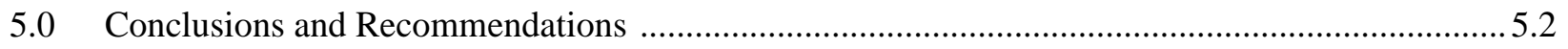

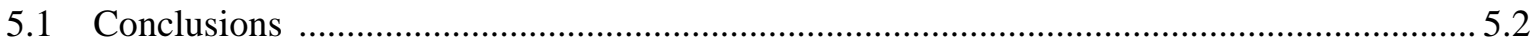

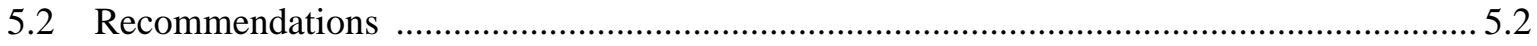

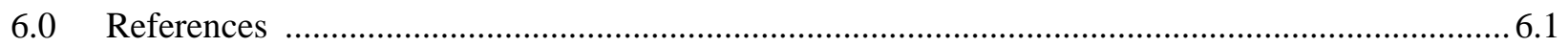




\section{Tables}

2.1 Sampling Requirements

2.1

4.1 Relevant WTP M1 and M3 Milestones and Schedule...

4.1 


\subsection{Introduction}

This document is a fiscal year-end progress report covering work completed during the first phase of a three-phase project. Note that this is a progress report since not all of the Phase 1 scope is finished. A final report on Phase 1 work will be issued when this work is completed in FY08. The work for each phase of the project is described below:

- Phase 1: In this phase, Pacific Northwest National Laboratory (PNNL) will produce a technical overview and assessment of the baseline waste feed delivery mixing system. This overview will be compiled from existing tank farm planning and design documents supplemented by interviews with tank farm staff. The overview will include 1) mixing systems and operation, 2) physical properties, and 3) mixing requirements (mixing, sampling, and flammable gas). The assessment of the baseline will provided by PNNL staff with experience and expertise in jet mixing system performance and waste properties and their behavior. It will include applying relevant material from existing research reports. The final report will identify areas where gaps in the technical basis exist and will recommend activities to estimate the magnitude of technical risk in those areas.

- Phase 2: PNNL staff will conduct the activities to estimate the technical risks for the gaps identified in Phase 1.

- Phase 3: PNNL, working with CH2M HILL, will design a technical program that incorporates testing and modeling to reduce the technical risks identified in Phase 1 to quantify waste feed delivery system performance and minimize technical risk. Phase 3 will be contingent upon the results of Phase 2, indicating that some of the technical risks could lead to system performance deficiencies or failure.

The initial assessment of the baseline waste feed delivery mixing system that is required as part of the Phase 1 work scope is included in Section 2 and 3. Section 4 follows with a summary of current WTP activities that are relevant to this project. 


\subsection{Mixing System Requirements}

The primary function of the planned mixing systems is to suspend the solids so they can be retrieved and transported to the WTP. The tank farm contractor (TFC) plans to mix Envelope D slurries with one or two large submersible mixer pumps (using the current 300-HP, project W-211 design) in the staging DST (Rieck 2004). At least 180 days before transferring the waste slurry into the staging tank, the TFC must sample the slurry and send it to the WTP for analysis (one document assumes that the 222-S Laboratory will perform this analysis) to ensure that it meets the waste feed delivery criteria. The sampling requirements are described in the Interface Control Document for Waste Feed (Pennington 2003), and the Regulatory Data Quality Objectives (RDQO) (Meehan 2004). The sampling requirements are different in each document and are listed in columns 2 and 3 in Table 2.1.

Table 2.1. Sampling Requirements

\begin{tabular}{|c|c|c|}
\hline $\begin{array}{c}\text { Sampling } \\
\text { Activity/Parameter }\end{array}$ & $\begin{array}{c}\text { Interface Control Document } \\
2003 \\
\end{array}$ & RDQO 2004 \\
\hline Mixing & $\begin{array}{l}\text { “...the tank waste contents are } \\
\text { mobilized and/or blended in the } \\
\text { isolated staging tank with a mixer } \\
\text { pump.” }\end{array}$ & $\begin{array}{l}\text { "Periodic mixing should be performed as } \\
\text { possible in order to minimize settling and } \\
\text { ensure representativeness of feed } \\
\text { characterization data...” }\end{array}$ \\
\hline Grab samples & 8 grab samples of $250 \mathrm{~mL}$ of waste. & $\begin{array}{l}\text {...total of at least } 350 \mathrm{~g} \text { of solids and } 500 \\
\mathrm{~mL} \text { of liquid. }\end{array}$ \\
\hline Grab sample locations & $\begin{array}{l}\text { Equally spaced under one riser, from } \\
1 \mathrm{ft} \text { above bottom or solids level if } \\
\text { settled, to liquid surface. }\end{array}$ & $\begin{array}{l}\text { Five samples under two risers, equally } \\
\text { spaced depths (minimum of } 10 \text { grabs } \\
\text { total). Additional grab samples as } \\
\text { required to make required quantities. } \\
\end{array}$ \\
\hline Core samples & $\begin{array}{l}\text { "In the case core sampling is used to } \\
\text { sample the tank....." }\end{array}$ & $\begin{array}{l}\text { "If the solids have settled considerably } \\
\text { after mixing or if the tank contents have } \\
\text { not been mixed, core samples will be } \\
\text { required.” }\end{array}$ \\
\hline Core sample locations & not specified & $\begin{array}{l}\text { “...one core sample from two different } \\
\text { risers (minimum of } 2 \text { cores total).” }\end{array}$ \\
\hline
\end{tabular}

The Envelope D feed delivery criteria are quite complex and require extensive chemical and radiochemical analyses to assess. This is complicated by the fact that current feed staging plans include up to 100 inches of solids (Kirkbride et al. 2007), a challenging mixing regime where we have little operational experience. ${ }^{\text {(a) }}$ While the sampling requirements appear to assume uniform radial and azimuthal solids concentrations, there are no specific requirements or criteria stated for sample representativeness in the staging double-shell tank (DST). However, the stated quality assurance requirements (Section 9.6 of the RDQO) are said to contain stringent criteria for samples (these have not been reviewed by the authors).

In general, mixing systems never achieve uniform solids distributions. This statement is relevant for the mixer pump systems selected for deployment at Hanford. Approximate radial uniformity can be achieved in some cases; however, vertical stratification is a direct consequence of the action of gravity on the

(a) Apart from SY-101 mixer pump testing (see Section 3.2). 
particles. In the limit of solid particles that are very fine and have low density relative to the liquid, practical uniformity can be achieved. However, if larger and/or denser particles are present, significant stratification can occur.

It is probably not possible, or at least will be extremely difficult, for the TFC to meet these implied requirements, even with improved mixing systems. Further, there is currently no documented basis to show what is possible with the baseline design. If the TFC knew what level of slurry uniformity the current W-211 mixer pumps can produce, what kind of sampling strategy would be required to claim representativeness with this level of mixing, and what improvements would be necessary to increase mixing uniformity, they would be able to negotiate revisions to the RDQO from a solid basis. This, therefore, must be the objective of a combined mixing-sampling test program. The present state of knowledge about slurry mixing is briefly summarized in Section 3. 


\subsection{Mixing System Performance}

Ultimately, the question that needs to be answered is how uniform a slurry will the baseline dual opposed mixer pump design practically provide. None of the previously published mixer pump experience has been able to answer that question. The following is a summary of the mixer pump data, simulation results, and observations from reports and experiences that address mixing system performance and improvements.

\subsection{Savannah River Tank Mixing}

References provided by CH2M HILL report Savannah River Site (SRS) mixing tests and waste transfers using 1) opposed 1/4-inch water nozzles at up to 4,000 psi (Hill 1967), 2) four 150-HP dual-nozzle, bottom inlet jet pumps, and 3) one long-shaft 300-HP dual-nozzle, bottom inlet, advanced design mixer pump (Leishear et al. 2004). None of these activities achieved a clean tank, and the two later ones had problems with apparent pump plugging either due to obstructions or sludge collapse. In all cases, slow rotation provided better mobilization over a greater distance than either fast rotation or indexed rotation. Transfer pump placement relative to the mixer pump was found to be very important in providing a mobile slurry to the transfer pump.

PNNL staff studied the advanced design mixer pump for operation at SRS. Enderlin et al. (2003) discussed technical issues and presented recommendations for operating the advanced design mixer pump in Tank 18 at SRS. Also presented are the results obtained from simulated scaled pump-down tests carried out in the 1/4-scale DST test facility at PNNL. The ability of the Tank 18 retrieval system to mobilize the solid waste and transport it through the retrieval pump, efficiently removing the solids from the tank, are evaluated.

\subsection{SY-101 Mixer Pump}

SY-101's mixer pump is a 150-HP submersible with opposed 2.6-inch (6.6-cm) nozzles and a high inlet elevation ( 18-ft [ 5.5 m]) (Stewart et al. 1994, Johnson et al. 2000). This pump had a chronic oil temperature limitation problem that allowed it to run less than one hour at full speed with a wait of one day between runs. The normal mode was three runs per week, each indexed 30 degrees from the last, shifting the starting orientation 15 degrees each complete rotation. This schedule was effective in mobilizing enough solids to prevent gas retention at depth, although it eventually resulted in the unacceptable growth of a thick crust layer that was cured only by waste transfer, dilution, and mixing (performed with the same pump).

The pump jet eventually mobilized solids down to 4 inches $(10 \mathrm{~cm})$ off the bottom out to a 27-ft (8.2-m) radius and maybe farther, but it probably did not reach the outside corner (Stewart et al. 1994). There was always about a 100-inch (2.54-m) loosely settled layer on the bottom, with finer solids suspended all the way to the base of the crust (350-380 inches) (8.9-9.7 m). 


\subsection{AZ-101 Mixing Tests}

The Hanford Tank 241-AZ-101 mixer pumps were originally conceived in the late 1980s to provide feed for a demonstration of waste pretreatment in B-plant. This project was eventually canceled and became a DST waste retrieval demonstration with two 300-HP, long-shaft, dual-nozzle pumps that were installed by the W-151 project in 1996. The pumps were not run until the actual test in 2000. It was not a very appropriate demonstration because AZ-101 contained only 15 to 20 inches $(0.31$ to $0.51 \mathrm{~m})$ of solids, and the mixer pump jets were actually above that level.

The test results claimed that “...pumps could mobilize 95-100 percent of the solids and an effective cleaning radius of at least $37.4 \mathrm{ft}(11.40 \mathrm{~m})$ ” where the tank radius is $37.5 \mathrm{ft}(11.43 \mathrm{~m})$. However, "Full power operation of the two mixer pumps suspended only 41 percent of the sludge. The remaining 59 percent of the sludge was either partially suspended or pushed around the bottom of the tank" (Carlson et al. 2001). Settling was much more rapid than expected. Measurements were complicated by this fast settling and the limitation that the instruments that could not be operated with the pumps running. Major recommendations were that all transfers, both in and out, be made with mixer pumps running and that all instruments be designed to operate with the mixer pumps running.

\subsection{W-211 Mixer Pump Development}

The W-211 mixing system consists of two 300-HP submersible pumps with dual opposed 6-inch (15-cm) nozzles (Rieck 2004). The W-211 functional criteria state requirements for nozzle velocity, fluid density, rotation capability, etc., but no technical basis is documented for these requirements. The pumps have never been tested, but extensive computational simulations have been performed by PNNL using the TEMPEST code (using the version with capability to model erosion of solids with a yield stress) (Onishi and Wells 2004). The results of these simulations have been claimed as the technical basis for mixing performance, although the predictions of this model have not been formally validated.

Simulations of two pumps operating in Tank AY-102 are illustrative (Onishi and Wells 2004). AY-102 has 186 inches $(4.7 \mathrm{~m})$ of supernatant liquid and 62 inches $(1.6 \mathrm{~m})$ of sludge that is fairly strong with a yield stress of 1,090 to 2,230 Pa. TEMPEST simulations showed that two rotating mixer pumps would erode $89 \%$ of the sludge with shear strength of 1,090 Pa up to $41 \mathrm{ft}(12.5 \mathrm{~m})$ away from the mixer pumps but would not mobilize the bottom 2.5 inches $(6.4 \mathrm{~cm})$ of sludge or the sludge in areas next to the tank wall more than $26 \mathrm{ft}(7.9 \mathrm{~m})$ away from the pumps. Once the sludge is mobilized, the solids are predicted to be uniformly suspended within the tank within a 1-vol\% concentration variation except those within a few inches of the bottom. Assuming a shear strength of 2,230 $\mathrm{Pa}$, the two pumps would erode $85 \%$ of the sludge up to $38 \mathrm{ft}(11.6 \mathrm{~m})$, leaving only the bottom 2.5 inches $(6.4 \mathrm{~cm})$ of sludge. The mixer pumps would also leave the sludge at the tank wall $20 \mathrm{ft}(6.1 \mathrm{~m})$ or more from the pumps. The mobilized solids were predicted to be uniformly suspended except within a few inches of the tank bottom.

Another simulant study looked at the effect of turning the pump upside down so the inlet was above the jets (Onishi et al. 2003a, b). This would allow the jets to be placed closer to the tank bottom, making the jets more effective but requiring a higher slurry depth for the pump to operate. The TEMPEST simulations showed that the new configuration would mobilize significantly more solids than the standard configuration. 
Onishi et al. (2000) also evaluated using two 300-hp mixer pumps to mix solid and liquid radioactive wastes stored in Hanford DST 241-AZ-102. The study confirmed the adequacy of a 3-inch (7.6-cm) pipeline to transfer the resulting mixed waste slurry to the AP Tank Farm and ultimately to a planned WTP on the Hanford Site.

In addition, the mixing performance of the Lawrence pump, which has injection nozzles at the top, was compared with an alternative pump that has injection nozzles at the bottom to determine the optimal elevation for the alternative pump (Onishi et al 2002). Sixteen cases were evaluated: two sludge thicknesses at eight levels. A two-step evaluation approach was used. Step 1 evaluated all 16 cases with the non-rotating mixer pump model, and Step 2 further evaluated four of those cases with the more realistic rotating mixer pump model. The TEMPEST code was used.

Erian et al. (2002) investigated whether time-phase separation between pump head oscillations affects overall sludge mobilization. If a mixing jet from one pump happens to follow temporarily the path of the lead mixing jet, it may be possible to prevent or slow down the resettling of the heavy solid particles, maintaining them in suspension. If a retrieval pump were operating at the same time, it could facilitate removal of such particles. Preliminary experiments were carried out to observe whether time-phase separation had some influence on the overall mobilization. The time-phase separation technique was used to mobilize and retrieve most of the radioactive waste from Tank D8-2 at the West Valley Demonstration Project.

\section{5 $\quad 1 / 12^{\text {th }}$-Scale Uniformity Testing}

A significant start toward the direct goal of predicting mixture uniformity in the DST mixer pump system began in 1990. A strategy was developed for a combined experimental and computational program (Bamberger et al 1990, Liljegren and Bamberger 1992). The strategy recommended scaled testing to be conducted in 1/12- and 1/4-scale models of a million-gallon DST. To support this effort, a 1/4-scale vessel was constructed to complement the existing 1/12-scale vessel. The test plan for the initial 1/12scale tests was completed next (Bamberger and Liljegren 1994). This was followed by the tank uniformity experiments in the 1/12-scale model of a jet mixed tank in 1995. The strategy plan was released only to the client in 1990, and the experimental results report was completed in draft form only in 1995 but was never published due to lack of project funds. So that both reports can be used in the current project, they have been published for general distribution. The strategy report is unchanged and keeps its initial document number (Bamberger et al, 1990). The experimental results report is a new document (Bamberger et al, 2007).

The strategy is still valid and, with improved understanding and updated technology, could serve, in part, as a basis for a test program for the waste feed delivery system. The experimental results and correlation included in the second report form the basis for the initial evaluation of mixer pump performance. Coupled with the planned 1/4-scale tests that were not completed, these tests would provide the ability to develop improved correlations. The 1/12-scale tests were conducted over a range of mixer pump operating conditions, including $25,50,75$, and $100 \%$ of $\mathrm{U}_{0} \mathrm{D}_{0}$ (the scaled parameter to model pump operation), thereby providing the ability to address curvature in the correlation. During these initial tests, nozzle diameter was not varied, and the test was conducted at a single, relatively small scale. In spite of these limitations, this testing was a very good start toward obtaining the information that is needed. To provide continuous monitoring of the solids concentration during these tests, ultrasonic sensors were 
developed (Bamberger and Greenwood 2004a, b). This instrumentation was used to provide real-time measurements of the concentration profiles obtained during the 1/12-scale tests (Bamberger and Meyer 2001).

The correlation presented in the experimental results report gives the solids concentration achievable with a single mixer pump as a function of jet velocity, particle size, and liquid viscosity. One can attempt to extend the result to include the effects of solids density, nozzle diameter, and vessel fill level by virtue of dimensional reasoning and known functionality of these parameters for pulse jet mixing (Section 4). It can also be approximately extended to account for two mixer pumps. It is reasonable that the correlation be extended and applied to the current design, considering a broad range of waste properties. While results of this application of these very limited test results must be interpreted cautiously, this is the first opportunity to use hard test data to evaluate the design. 


\subsection{Relevant Activities in the WTP Mixing Program}

A significant amount of work has been performed and is ongoing for the WTP that is directly or indirectly applicable. Pulse jet mixers have much in common with rotating jet mixers in terms of physical principles. Issues surrounding waste physical and rheological properties are essentially the same, both in terms of establishing a design basis for the mixing systems and in the challenge of designing for wideranging waste behavior and limited characterization data specific to the physics of mixing.

The WTP is using a coordinated strategy to rating the mixing system designs by 1 ) determining realistic ranges for waste properties, 2) rating mixing system design performance via comprehensive scaled testing, and 3) establishing and refining actual mixing system requirements, based in part on observed test results. The "M1" task has completed concerted efforts to establish best-available cohesive property ranges and associated inventory percentages for Hanford waste (Poloski et al. 2007). These results are being used to set baseline noncohesive and cohesive waste properties for use in vessel mixing tests under the "M3" program. The distinctions between noncohesive and cohesive properties present very different mixing environments. Simulants are being developed for testing both types of slurries. The "M12" program will develop simulants that display physical and chemical properties of the variety of waste types and will test them in a pretreatment pilot plant.

The test program relies on a solid technical foundation and is clear in its approaches and goals. A parametric approach (Bamberger and Meyer 2007) is being used wherein mixing system performance is determined over a range of properties, as opposed to testing a "representative" simulant. This parametric approach provides the maximum amount of information that can be used to understand the limits of the current design and explore design options for improved mixing.

The establishment of vessel-specific mixing requirements is an ongoing effort and is indeed challenging. However, the process continues to move forward. As more test data become available, the requirements will be challenged and refined. Ultimately, mixing system design changes may be necessary; but only after the ramifications of the current design are well understood and other engineering solutions are explored.

Initial test results for solids suspension with PJMs suggests functionality similar to what was measured in the 1/12 scale uniformity (Bamberger et al. 2007b). As more data become available, the understanding into the basic scaling and mixing performance characteristics will become clearer. This should help focus on the key technical issues surrounding submerged jet mixing. Relevant milestones for "M1" and "M3" programs and their current scheduled completion dates are shown in Table 4.1. Simulant development and the initial phase of testing in the "M12" pilot plant are planned for completion in 2008.

Table 4.1. Relevant WTP M1 and M3 Milestones and Schedule

\begin{tabular}{||l|l||}
\hline \multicolumn{1}{|c|}{ Milestone } & \multicolumn{1}{c|}{ Scheduled Completion } \\
\hline M1 Rheology and Settling Behavior Report & October 2007 \\
\hline M1 Reference Testing Final Report & May 2008 \\
\hline M3 Phase 1 Letter Report & August 2008 \\
\hline
\end{tabular}




\subsection{Conclusions and Recommendations}

\subsection{Conclusions}

PNNL experience plus review of PNNL project and TFC reports supports the following conclusions regarding the current waste feed delivery system:

- Large, powerful mixing pumps like those specified by W-211 will likely be able to mobilize most, but not all, of the settled solids in a tank. It appears very unlikely that a staging tank would accumulate a deep layer of solids with such pumps mixing the tank during transfers. There are no satisfactory test data to prove or quantify either of these assertions.

- Mixing will not be entirely uniform, and settling will be relatively rapid after mixing ceases. The degree and orientation of nonuniformity are unknown; no published data exists from tests that have been performed to quantify the degree of uniformity.

- It is not practical to attempt to achieve truly uniform mixing for the purposes of sampling, but good sample representativeness is likely achievable. Tests need to address representativeness more than uniformity.

- The method of sampling and its location relative to the mixer pumps will likely have a strong influence on sample representativeness.

- The previously unpublished 1/12th scale uniformity tests (Bamberger et al. 2007b) represent the only directly useful data in rating mixing performance, although the test conditions are limited and scale-up data are lacking.

\subsection{Recommendations}

To complete the Phase 1 objectives, identification of remaining technical gaps should include those being filled by WTP. This can be assessed with further progress and completion of major WTP investigations during FY 2008. With these gaps identified, Phase 2 can begin with an assessment of their consequences in terms of risk. The earlier mixing-sampling test program should be considered along with the WTP test program and results as guidance to possible approaches to Phase 3, the test program that will close remaining technical gaps for the waste feed delivery tank mixing system.

It is recommended that $1 / 12^{\text {th }}$ scale test data (Bamberger et al. 2007b), together with relevant mixing data collected within the M3 task, be used to the full extent in evaluating mixing system performance. Additionally, if a limited number of tests were carried out in the 1/12-scale system, the resulting data, along with scale-up information from the M3 mixing program, could result in a correlation that could be used to obtain a reasonable estimate of mixing performance. 


\subsection{References}

Bamberger JA, LM Liljegren, and PS Lowery. 1990. Strategy Plan - A Methodology to Predict the Uniformity of Double-Shell Tank Waste Slurries Based on Mixing Pump Operation. PNNL-7665, Pacific Northwest National Laboratory, Richland Washington.

Bamberger JA and LM Liljegren. 1994. Test Plan for 1/12-Scale Scoping Studies for the Double-Shell Tank Uniformity Task. PNL-8900, Pacific Northwest National Laboratory, Richland, Washington.

Bamberger JA and PA Meyer. 2001. “Using Mixer Pump Jets to Maintain Solids in Suspension.” ASME 2001 Fluids Engineering Division Summer Meeting. FEDSM2001-18223 (PNNL-SA-34149), Pacific Northwest National Laboratory, Richland, Washington.

Bamberger JA and PA Meyer. 2007. "Characterizing Pulsating Mixing of Slurries." Proceedings of FEDSM2007 5th Joint ASME/JSME Fluids Engineering Conference. American Society of Mechanical Engineers, New York.

Bamberger JA, LM Liljegren, CW Enderlin, PA Meyer, MS Greenwood, PA Titzler, and G Terrones. 2007. One-Twelfth-Scale Mixing Experiments to Characterize Double-Shell Tank Slurry Uniformity. PNNL-16859, Pacific Northwest National Laboratory, Richland, Washington.

Bamberger JA and MS Greenwood. 2004a. "Using ultrasonic attenuation to monitor slurry mixing in real time.” Ultrasonics, Vol. 42, pp. 145-148. PNNL-SA-40033, Pacific Northwest National Laboratory, Richland, Washington.

Bamberger JA and MS Greenwood. 2004b. "Measuring fluid and slurry density and solids concentration noninvasively.” Ultrasonics, Vol. 42, pp. 563-567. PNNL-SA-40035, Pacific Northwest National Laboratory, Richland, Washington.

Carlson AB, PJ Certa, TM Hohl, JR Bellomy III, TW Crawford, DC Hedengren, AM Templeton, HS Fisher, SJ Geelhood, DG Douglas, and WJ Ulbricht Jr. 2001. Test Report, 241-AZ-101 Mixer Pump Test. RPP 6548, CH2MHILL Hanford Group, Inc., Richland, Washington.

Enderlin CW, G Terrones, CJ Bates, BK Hatchell, and B Adkins. 2003. Recommendations for Advanced Design Mixer Pump Operation in Savannah River Site Tank 18F. PNNL-14443, Pacific Northwest National Laboratory, Richland, Washington.

Erian FF, O Mullen, and MI Kellogg. 2002. Experience and Operational Improvements, Mixer Pump Performance. PNNL-13756, Pacific Northwest National Laboratory, Richland, Washington.

Hill AJ. 1967. Removal of Sludge from High Activity Waste Tanks. DP-1093, E.I. DuPont de Nemours \& Company, Savannah River Laboratory, Aiken, South Carolina. 
Johnson GD, NW Kirch, RE Bauer, JM Conner, CW Steward, BE Wells, and JM Grigsby. 2000. Evaluation of Hanford High-Level Waste Tank 241-SY-101. RPP-6517 Rev. 0, CH2MHILL Hanford Group, Inc., Richland, Washington.

Kirkbride RA et al. 2007. Tank Farm Contractor Operation and Utilization Plan. HNF-SD-WM-SP-012 Rev. 6, CH2M HILL Hanford Group, Inc., Richland, Washington.

Leishear RA, MJ Augeri, M Hubbard, JL Thomas, SY Lee, RA Dimenna, and DB Stefanko. 2004. ADMP Mixing of Tank 18F Sludge: History, Modeling, Testing, and Results. WSRC-TR-2004-00036, Westinghouse Savannah River Company, Aiken, South Carolina.

Liljegren LM and JA Bamberger. August 1992. "A Methodology to Predict the Uniformity of DoubleShell Waste Slurries Based on Mixer Pump Operation.” American Society of Chemical Engineers National Summer Meeting, Minneapolis. PNL-SA-20281, Pacific Northwest National Laboratory, Richland, Washington.

Meehan JL. 2004. Regulatory Data Quality Objectives Optimization Report. 24590-WTP-RPT-MGT-04001 Rev. 0, Bechtel Hanford Inc., Richland, Washington.

Onishi Y and BE Wells. 2004. Feasibility Study on Using Two Mixer Pumps for Tank 241-AY-102 Waste Mixing. PNNL-14763, Pacific Northwest National Laboratory, Richland, Washington.

Onishi Y, BE Wells, ST Yokuda, and G Terrones. 2003a. Feasibility Study on Using a Single Mixer Pump for Tank 241-AN-101 Waste Retrieval. PNNL-14105, Pacific Northwest National Laboratory, Richland, Washington.

Onishi Y, DS Trent, ST Yokuda, CA Majumder, CA Rieck, and EW Martinen. July 2003b. "Optimal Pump Elevation and Configuration for Mixing Erosion-Resisting Radioactive Tank Waste.” Proceedings of FEDSM'03 4TH ASME_JSME Joint Fluids Engineering Conference. ASME, New York.

Onishi Y, KP Recknagle, and BE Wells. 2000. Pump Jet Mixing and Pipeline Transfer Assessment for High-Activity Radioactive Wastes in Hanford Tank 241-AZ-102. PNNL-13275, Pacific Northwest National Laboratory, Richland, Washington.

Onishi Y, ST Yokuda, and CA Majumder. 2002. Optimal Elevation and Configuration of Hanford's Double-Shell Tank Waste Mixer Pumps. PNNL-13913, Pacific Northwest National Laboratory, Richland, Washington.

Poloski AP, BE Wells, JM Tingey, LA Mahoney, MN Hall, SL Thomson, GL Smith, ME Johnson, JE Meacham, MA Knight, MJ Thien, JJ Davis, and Y Onishi. 2007. Estimate of Hanford Waste Rheology and Settling Behavior. PNNL-16857 (WTP-RPT-154 Rev A), Pacific Northwest National Laboratory, Richland, Washington.

Pennington L. 2003. ICD-19 - Interface Control Document for Waste Feed. 24590-WTP-ICD-MG-01019, U.S. Department of Energy Office of River Protection, Richland, Washington. 
Rieck CA. 2004. Submersible Mixer Pump. W-211-SMP-P6 Rev. 0, CH2M HILL Hanford Group, Inc., Richland, Washington.

Stewart CS, JD Hudson, FR Friley, FE Panisko, ZI Antoniak, TE Michener, JG Fadeff, LF Efferding, JJ Irwin, NW Kirch, and DA Reynolds. 1994. Mitigation of Tank 241-SY-101 by Pump Mixing: Results of Full-Scale Testing. PNL-9959, Pacific Northwest National Laboratory, Richland, Washington. 


\section{Distribution}

No. of

Copies

\section{Onsite}

5 CH2M HILL Hanford Group, Inc.

$\begin{array}{ll}\text { PK Brockman } & \text { H6-03 } \\ \text { JO Honeyman } & \text { H6-03 } \\ \text { M Knight } & \text { R2-58 } \\ \text { M Thien } & \text { H6-03 } \\ \text { D Washenfelder } & \text { R2-58 }\end{array}$

7 Pacific Northwest National Laboratory

$\begin{array}{ll}\text { JM Bamberger } & \text { K7-15 } \\ \text { JA Fort } & \text { K7-15 } \\ \text { GB Josephson } & \text { K9-69 } \\ \text { PA Meyer } & \text { K7-15 } \\ \text { CW Stewart } & \text { K7-15 } \\ \text { Information Release (2) } & \text { P8-55 }\end{array}$

Distr.1 